\title{
Adsorption in Jar-Test system: a study of the physico-chemical interactions of the chitosan biopolymer with the textile dye DO 2GL
}

Carolina Rosai Mendes ${ }^{1}$, Guilherme Dilarri ${ }^{1}$, Ederio Dino Bidoia ${ }^{1}$, Renato Nallin Montagnolli ${ }^{1}$

\author{
${ }^{1}$ Department of Biochemistry and Microbiology, São Paulo State University (UNESP), 24-A Avenue, 1515, CEP: 13506- \\ 900, Rio Claro, SP, Brazil. \\ e-mail: carolina_rosai@hotmail.com
}

\begin{abstract}
The incorrect disposal of contaminated effluents from textile industries is a major contribution to their environmental impact. We aimed to use the chitosan biopolymer from industrial sources as a potential adsorbent agent. The experiments were performed in Jar-Test simulating an industrial scale treatment. Both $\mathrm{pH}$ and mass variations were analyzed. Our UV spectra results showed that all datasets fitted to the Langmuir model, indicating the formation of monolayers. Kinetics studies confirmed that adsorption follows a pseudo-second order model, in addition to a chemisorption pattern during adsorption. Kinetics studies also demonstrated intraparticle diffusion, which confirmed a strong adsorbate/adsorbent interaction with the dye. The Jar-Test proved to be an efficient system to simulate treatment of effluents on an industrial scale, thus ranking chitosan powder as a good adsorbent and eligible to future large-scale applications.
\end{abstract}

Keywords: chitosan, intraparticle diffusions, chemisorption, isotherms, kinetics

\section{INTRODUCTION}

Water pollution is a major worldwide problems that has been constantly aggravated by increasing anthropogenic activities. The residues of industrial processes and wastewater from domestic sewage are among the pollution sources that are often incorporated into rivers, especially when adequate and effective treatment methods are lacking. In this context, the textile industry is responsible for generating bulk effluents containing mainly synthetic dyes and toxic organic compounds, such as benzene, toluene, ethylbenzene, naphthalene, anthracene and xylene [1]. Circa $10 \%$ of all dyestuffs produced or processed by the textile industries are directly disposed as effluents [2], as the textile industry consumes approximately 10,000 tons per year of synthetic dyes [3]. Once in the environment, dyes and their derivatives may present high toxicity levels with mutagenic and carcinogenic effects on exposed organisms [4]. Moreover, the high organic load released into effluents changes local ecosystems due to the increase in water turbidity. The modified environment hinders the penetration of the solar radiation, which can further disturb the photosynthetic activity, decrease gas solubility and reduce the oxygen uptake rates [5]. Furthermore, the disposal of textile wastewaters lead to bioaccumulation and ecotoxicological processes [6].

There are currently several classes of synthetic dyes available in the textile market: acid, azoic, reactive, direct, dispersed, metallized, bleach and sulfonic. Approximately $60 \%$ of the dyes are azoic, being one of the groups of higher environmental impacts. This class often present more than one complex aromatic chain. In general, the functional chromophore groups are a result of the interaction between azo functions ($\mathrm{N}=\mathrm{N}-$ ) and aromatic species in the dye molecules [7]. However, the reductive cleavage of azo bonds in azoic dyes generate toxic and carcinogenic amines [3].

The removal of these dyes from effluents has been studied by physicochemical methods such as ozonization [8], photo-electrochemical degradation [9], subcritical flow [10]; and biological methods, such as microbiological degradation [11]. However, the physicochemical methods application costs are much higher, whereas biological methods require a large treatment area and longer effluent retention time. Therefore, dye waste management ends up being unfeasible by the lack of optimal applicability on an industrial scale.

Adsorption is presented as an alternative towards the treatment of textile industry waste. Its viability is due to the availably of many low-cost adsorbent materials. Most adsorbent substrates are biodegradable, easily obtainable in nature and, more importantly, obtained from pre-existing waste. Adsorption is considered a 
very efficient technique compared to other treatment methods, due to its simplicity of design and operation, associated with its efficacy and minimum to none toxic output [12]. Different types of materials have been proposed as good adsorbents, however, activated carbon remains as the most used adsorptive material in processes due to their low cost, suitable physical properties, and regional availability on an industrial scale [13].

A highly adsorbent biopolymer be obtained in fishing activities with shrimp and other arthropods as a replacement to activated carbon. Chitosan is a biopolymer obtained by deacetylation of chitin from the exoskeleton of arthropods or fungal cell walls [15], often synthesized using the fishing residues such as crustacean shells. The world chitosan market share includes $60 \%$ nutraceuticals and food use, $17 \%$ flocculants, $5 \%$ cosmetics, $5 \%$ agriculture, $6.5 \%$ in the textile and paper industries and $6.5 \%$ in the pharmaceutical and medical industries [16]. Chitosan choice as an adsorbent material is aided by the fact that the fishing market waste itself has become an environmental problem, in which tons of shell residues are disposed daily. It may also represent an abundant source of biopolymers, as the annual global production of shrimp, crayfish, lobsters, and crabs is estimated at 1,44 million tons of dried biomass [14].

Chitosan is already reported in the literature as a good adsorbent material for dyes [15], but, to the best of our knowledge, no tests have yet been performed proposing commercial chitosan biopolymer as adsorbent material in textile industry. Thus, the aim of this work was to analyze the potential of industrial chitosan powder as a dye adsorbent. To evaluate the applicability of the material on an larger scale, the Jar-Test system was used to simulate the application in a textile effluent treatment in a real contamination scenario. The Jar-Test is a prospective small-scale simulator of an industrial effluent treatment. We selected the azo reactive dye Direct Orange 2GL as our contaminant to represent the synthetic dyes found in textile dyeing processes. Mathematical models of kinetics and isotherm were applied in the results to specify the main mechanisms of adsorbate/adsorbent interaction that occurred throughout the sorption process.

\section{MATERIALS AND METHODS}

\subsection{Chitosan}

The chitosan powder used in this study was obtained from Purifarma Chemistry \& Pharmaceutical Brazil-SP, being derived only from shrimp shells with physicochemical characteristics of $90 \%$ degree of deacetylation corresponding to $5.60 \times 10^{-3}$ mole of amino group per grams of biopolymer, particle size of 80 mesh and density of $0.38 \mathrm{~g} \mathrm{~mL}^{-1}$. Its chemical structure is shown in Figure 1 .

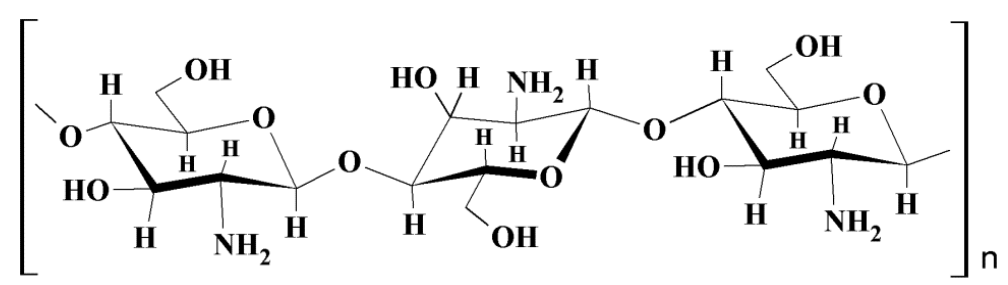

Figure 1: Chemical structure of chitosan.

\subsection{Direct Orange 2GL}

Direct Orange 2GL (DO 2GL) dye, Chemical Abstract Service (CAS) number: 1325-54-8 and molar mass of 299 moles was obtained from the company Dimacolor Industry Group Co. It is a stable dye on $\mathrm{pH}$ variation with its maximum absorbance at $415 \lambda$. The dye has reactive sulfonic groups, which confers solubility in aqueous medium, besides an azo functional group in its structure (Figure 2).

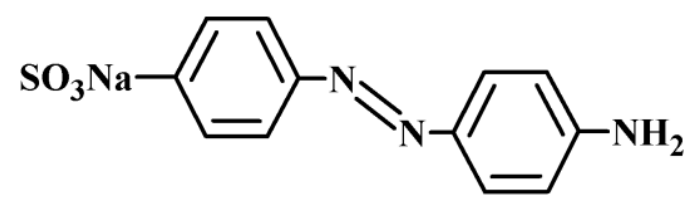

Figure 2: Chemical structure of the reactive dye Direct Orange 2GL. 


\subsection{Adsorption test using Jar-Test}

Adsorption assays with DO 2GL dye solution were performed through various mass concentrations of the chitosan powder: $0.2 ; 0.4 ; 0.6 ; 0.8$ and $1.0 \mathrm{~g}$. The Jar-Test equipment (Policontrol model FlocControl II), was adjusted for constant blade rotation at $60 \mathrm{rpm}$, with a maximum contact time of 3 hours, at room temperature of $25 \pm 2{ }^{\circ} \mathrm{C}$ (Figure 3 ).

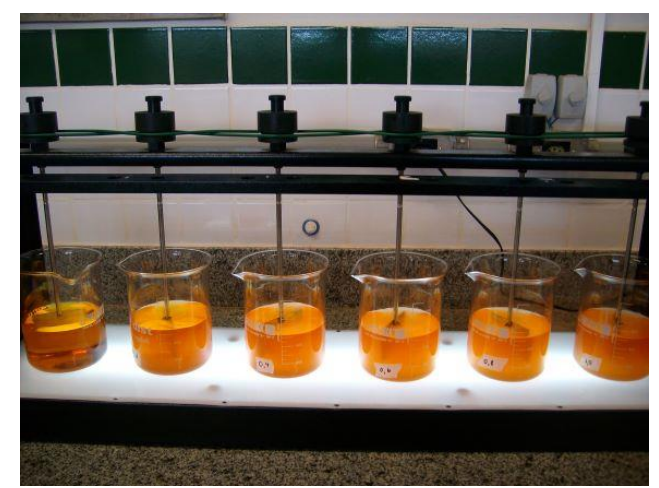

Figure 3: Jar-Test sistem used for dye adsorption assays.

A dye solution with a concentration of $8.36 \times 10^{-2} \mathrm{mmol} \mathrm{L}^{-1}\left(50 \mathrm{mg} \mathrm{L}^{-1}\right)$ was added to $500 \mathrm{~mL}$ in each vat where adsorption took place. The adsorption studies with mass variations were also conducted at different $\mathrm{pH}$ values (5.50 and 6.50), as this is the regulated range for the disposal of any treated effluent according to Brazilian environmental laws [17].

Aliquots of each sample were taken after the final test period, and thereafter they were centrifuged at $3000 \mathrm{rpm}$ for 10 minutes, thus separating the adsorbent from the solution. The aqueous phase was then measured in a UV-Vis spectrophotometer (Thermo Scientific model BioMate 3S) from 300 to $800 \mathrm{~nm}$, using quartz cuvettes with a $10 \mathrm{~mm}$ optical path. The dye concentration adsorbed per mass of adsorbent was calculated using Equation 1.

$$
q e=\frac{(\mathrm{Co}-\mathrm{Ce}) \cdot \mathrm{V}}{W}
$$

where $W$ is mass $(\mathrm{g}), V$ is the volume of the solution $(\mathrm{L}), C o$ is the initial concentration and $C e$ is the concentration of the dye in the solution $\left(\mathrm{mg} \mathrm{L}^{-1}\right)$ after adsorptions, and qe is the adsorption capacity at equilibrium per mass of chitosan powder $\left(\mathrm{mg} \mathrm{g}^{-1}\right)$.

The data obtained in this study were analyzed using the mathematical models of the isotherms of Langmuir (1918) [18] and Freundlich (1906) [19], which can determine the singular characteristics of the adsorption, besides being able to determine whether the sorption process is physical or chemical.

The Langmuir model (Equation 2) fits to adsorption datasets whose adsorbent is homogeneous. According to Langmuir isotherms, a specific chemical site of the adsorbent surface will interact with the adsorbate having a finite number of binding sites, thus forming a monolayer [20].

$$
q e=\frac{q m \cdot l \cdot C e}{1+C e \cdot l}
$$

where $q m$ is the maximum amount of dye adsorbed per mass of adsorbent at equilibrium $\left(\mathrm{mg} \mathrm{g}^{-1}\right)$ and $l$ is the Langmuir constant related to the affinity of the adsorbent and adsorbate $\left(\mathrm{L} \mathrm{g}^{-1}\right)$.

When linearizing the Langmuir model, we obtained the Equation 3. Through the linear regression of the graph of Celqe vs. $C e$ we found the values of the constants $q m$ and $l$.

$$
\frac{C e}{q e}=\frac{1}{l . q m}+\frac{C e}{q m}
$$

The Langmuir separation factor $(R l)$ was also calculated, using the Equation 4 proposed by McKay et al. (1982) [21].

$$
R l=\frac{1}{1+l \cdot C o}
$$


This model helped to determine if the adsorption was favorable or unfavorable. Depending on the $R l$ results, we considered $R l=0$ the adsorption to be irreversible, $R l=1$ linear, $R l>1$ unfavorable, and $0<R l<$ 1 favorable [21].

The Freundlich model (Equation 5), on the other hand, proposes that the surface of the adsorbent is heterogeneous. In other words, the surface has different sites of interaction with the adsorbate, and the occupation of these sites follows a descending order according to their interaction and energy. The decreasing and exponential occupation of the interaction sites lead to the formation of a multiple layer adsorption on the adsorbent [22].

$$
q e=K f \cdot C e^{1 / n f}
$$

where $K f$ is the Freundlich constant related with solid adsorption capacity $\left(\mathrm{L} \mathrm{g}^{-1}\right)$, and $n f$ is the adsorption constant.

The linearized Freundlich model (Equation 6) and the linear regression plot of lnqe vs. lnCe allowed th calculation of $K f$ and $n f$ values.

$$
\ln q e=\ln K f+\frac{1}{n f} \cdot \ln C e
$$

\subsection{Kinetics studies in Jar-Test}

The kinetic studies were performed separately, using Jar-Test equipment. We added $500 \mathrm{~mL}$ of dye solution with an initial concentration of $50 \mathrm{mg} \mathrm{L}^{-1}$, at $\mathrm{pH} 6.50$ and 5.50 , to each vat. Powdered chitosan $(1.0 \mathrm{~g})$ was added simultaneously to each vat. The equipment was adjusted for constant blade movement at $60 \mathrm{rpm}$, at room temperature $\left(25 \pm 2{ }^{\circ} \mathrm{C}\right)$. The dye concentration was monitored at a sequential interval of 10 minutes at a maximum observation time of 90 minutes. The solution aliquots were all centrifuged at $3000 \mathrm{rpm}$ for 10 minutes before each analysis in UV-Vis spectrophotometer.

For a better interpretation of the kinetic data, we used the mathematical models of pseudo-first order (Equation 7) proposed by Lagergren (1898) [23], and pseudo-second order (Equation 8) proposed by Ho and McKay (1998) [24].

$$
\ln (q e-q t)=\ln q e-k l . t
$$

and

$$
\frac{t}{q t}=\frac{1}{k s \cdot q e^{2}}+\frac{t}{q e}
$$

where $t$ is time in minutes, qt is the amount of dye adsorbed at time $t\left(\mathrm{mg} \mathrm{g}^{-1}\right), k l$ is the adsorption rate constant of the pseudo-first order model $\left(\mathrm{min}^{-1}\right)$, and $k s$ is the pseudo-second order rate constant $\left(\mathrm{g} \mathrm{mg}^{-1} \mathrm{~min}^{-1}\right)$.

Adsorbate is often not restricted to adsorbing only to surface layers, as its penetration into the adsorbent molecule may also occur. In order to evaluate this occurrence, we applied the mathematical model of the intraparticle diffusion proposed by Weber and Morris (1963) [25] (Equation 9).

$$
q t=K d i \cdot t^{0.5}+C
$$

in which $K d i$ is the constant of intraparticle diffusion rate $\left(\mathrm{g} \mathrm{mg}^{-1}\left(\mathrm{~min}^{0.5}\right)^{-1}\right)$ and $C$ is a constant related to the thickness of the diffusion layers $\left(\mathrm{mg} \mathrm{g}^{-1}\right)$.

Still, intraparticle diffusion can occur simultaneously with surface adsorption and may not be the driving factor of the reaction [22]. We applied the Equation 10 to identify simultaneous intraparticle diffusion, according to the Boyd et al. (1947) model [26].

$$
B t=-0.4977-\ln \left(1-\frac{q t}{q e}\right)
$$

In this case, if the $B t$ vs. $t$ plot passes through the graph coordinate plane origin, intraparticle diffusion is the dominant process in sorption [27]. 
The second Boyd model (Equation 11) was also used to calculate the effective diffusion coefficient.

$$
D i=\frac{r^{2} \cdot B b}{\pi^{2}}
$$

in which $D i$ is the effective diffusion coefficient $\left(\mathrm{cm}^{2} \mathrm{~s}^{-1}\right)$ of DO 2GL dye in the chitosan powder, $r$ is the average radius of the chitosan powder particle $(0.00885 \mathrm{~cm})$, and $B b$ is calculated from the graph of $B t$ as a function of $t$.

All the kinetic and adsorptive studies conducted in Jar-Tests were done in triplicates. Proper standard deviation (SD) analysis was applied to our data output and to the mathematical models fits using Equation 12.

$$
S D=\sqrt{\frac{1}{N-1} \sum_{i=1}^{N}\left(\frac{Q i e-Q i c}{Q i e}\right)^{2}}
$$

in which Qie and Qic $\left(\mathrm{mg} \mathrm{g}^{-1}\right)$ are experimental and calculated mass of dye adsorbed by adsorbents materials, and $N$ is the number of measurements made.

The graphs and chemical structures used in this work were designed using proprietary software Origin 6.10 and $\mathrm{ACD} /$ ChemSketch.

\section{RESULTS AND DISCUSSION}

Our adsorption study with Jar-Test showed that chitosan is a very dense powder. It decanted at the bottom of the vats after 3 hours. Although dense, the blades of the Jar-Test system had no difficulty in keeping constant stirring, thus proving that chitosan powder would be a viable material to upscaled industrial applications.

The sorption rate of the dye compared to the mass of the adsorbent material (Figure 4) showed that adsorption was more efficient at $\mathrm{pH} 5.50$.

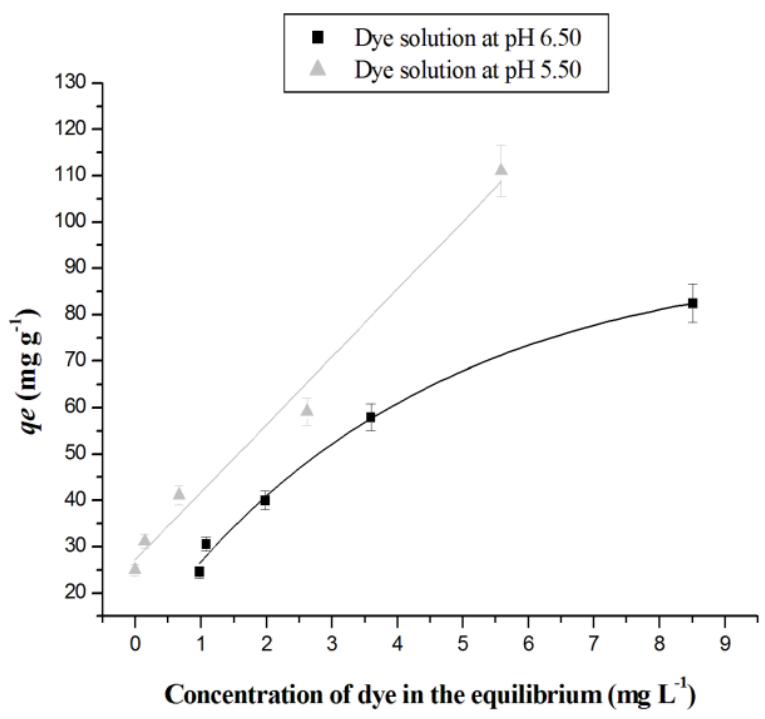

Figure 4: Amount of dye adsorbed per mass of chitosan powder.

Chitosan had an adsorption capacity of $24.615 \mathrm{mg} \mathrm{g}^{-1}$ at $\mathrm{pH}$ 6.50. In comparison, Safa [28] reported in a previous studies using rice husk that Direct Orange dye adsorption was $36.14 \mathrm{mg} \mathrm{g}^{-1}$ at $\mathrm{pH} 3.0$. The maximum adsorption achieved by both materials were similar. However, the use of chitosan in our study is more advantageous because the applied $\mathrm{pH}$ is much closer to neutral. Thus, no further adjustments to the $\mathrm{pH}$ of the treatment tank output is required before releasing the treated industrial wastewater. Changes in $\mathrm{pH}$ would increase the use of chemicals and the overall treatment costs. 
The isotherms (Table 1) confirmed that for both $\mathrm{pH}$ the adsorption fitted best to the Langmuir model (Figure 5), indicating that a specific site of the adsorbent is interacting with the DO 2GL dye, forming a monolayer.

Table 1: Adsorption isotherm parameters

\begin{tabular}{ccccccccccc}
\hline Chitosan powder & \multicolumn{3}{c}{ Langmuir isotherm } & \multicolumn{5}{c}{ Freundlich isotherm } \\
\hline $\mathrm{pH}$ & $\begin{array}{c}q m \\
\left(\mathrm{~L} \mathrm{~g}^{-1}\right)\end{array}$ & $\begin{array}{c}l \\
\left(\mathrm{~L} \mathrm{~g}^{-1}\right)\end{array}$ & $R l$ & $R$ & $S D$ & $\begin{array}{c}K f \\
\left(\mathrm{~L} \mathrm{~g}^{-1}\right)\end{array}$ & $n f$ & $R$ & $S D$ \\
5.50 & 111.482 & 1.292 & 0.0152 & 0.924 & 1.010 & 52.527 & 7.157 & 0.861 & 2.835 \\
6.50 & 111.607 & 0.310 & 0.0606 & 0.983 & 1.450 & 27.085 & 1.830 & 0.981 & 3.797 \\
\hline
\end{tabular}

No major variation was found when comparing $q m$ in both $\mathrm{pH}$ values, similarly to the values of $q e$ (Figure 5). The maximum sorption rates are likely equivalent in an ideal equilibrium. However, the values of $l$ indicated that the chitosan powder had a much higher adsorbate/adsorbent affinity when in more acidic medium. This result is corroborated when the values of $R l$ obtained are compared, as it almost approaches 0 in $\mathrm{pH} 5.50$, thus indicating that adsorption is close to irreversible. This result indicates chemical interactions that involve a shared and/or exchanged electron flow between the chitosan powder and the DO 2GL dye molecule. Even so, adsorption was also favorable when $\mathrm{pH} 6.50$, despite not showing high sorption affinity.
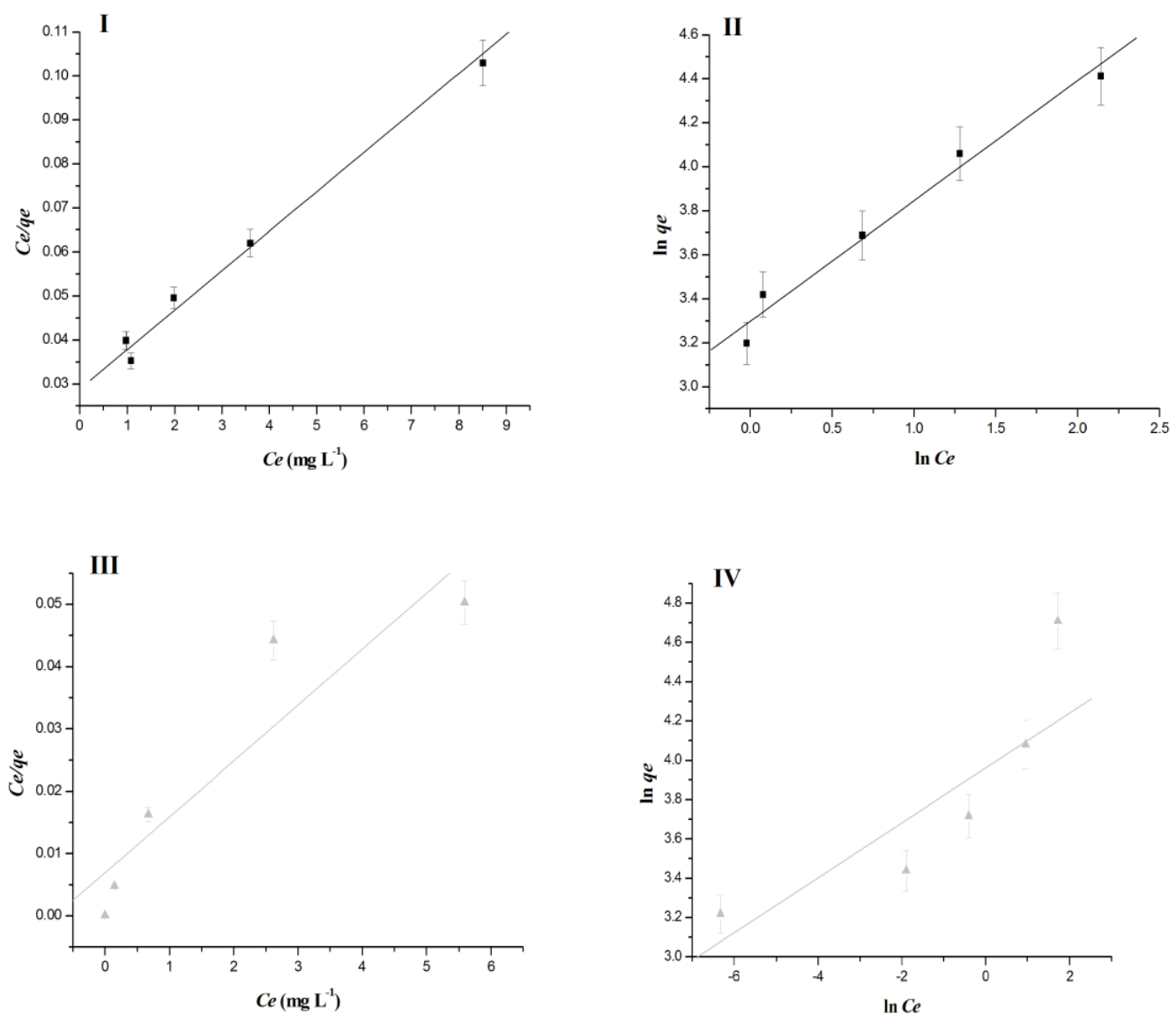

Figure 5: Adsorption isotherm models: I - Langmuir model in the solution at $\mathrm{pH}$ 6.50; II - Freundlich model in the solution at pH 6.50; III - Langmuir model in the solution at pH 5.50 and IV - Freundlich model in the solution at pH 5.50.

Although not following the Freundlich model (Figure 5), the $K f$ values indicated that solid/liquid adsorption capacity were higher at $\mathrm{pH} 5.50$, confirming a high interaction between adsorbent with adsorbate. In this case, even if adsorption does not fit the Freundlich model, both isotherm and values of $n f$ are greater than 
1. The surface interaction promoted by chitosan is homogeneous, reinforcing the best fit to the Langmuir isotherm for both $\mathrm{pH}$ values.

The kinetic studies showed that both materials reach the equilibrium of sorption almost at the same time (Figure 6), even in solutions with different $\mathrm{pH}$. The adsorption reaches the equilibrium 10 minutes earlier at $\mathrm{pH} 5.50$ than at $\mathrm{pH} 6.50$, which is not a relevant difference in industrial scale treatments.
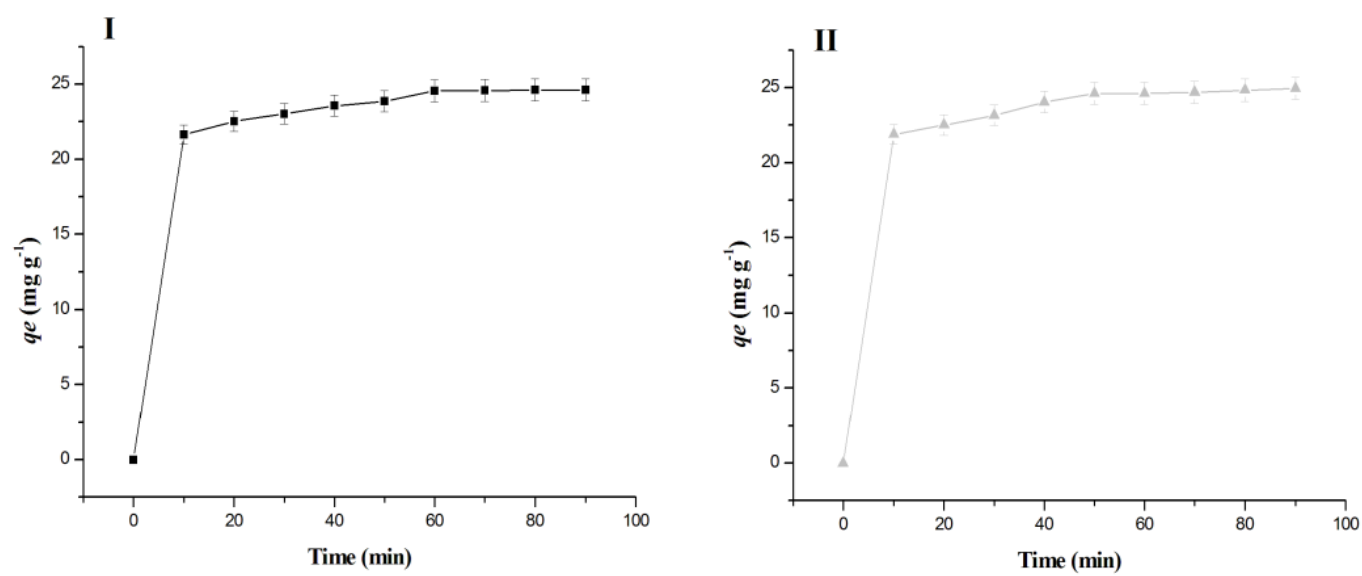

Figure 6: Kinetics studies plot: I - Experimental adsorption kinetics at pH 6.50 and II - Experimental adsorption kinetics at $\mathrm{pH} 5.50$.

Both $\mathrm{pH}$ and adsorption patterns correlate to the kinetic models of pseudo-second order (Table 2) according to the coefficients obtained in the kinetic studies. This result is corroborated by $q e_{(\exp )}$ and $q e_{(\text {cal }}$ that were much closer to the pseudo-second order model. An adsorption that follows the pseudo-second order model means that adsorption occurs by a chemical process [29], such as the data obtained in our isotherm studies.

Table 2: Kinetics studies parameters

\begin{tabular}{llcccccccc}
\hline \multicolumn{2}{c}{ Chitosan powder } & \multicolumn{3}{c}{ Pseudo-first order } & \multicolumn{3}{c}{ Pseudo-second order } \\
\hline $\mathrm{pH}$ & $\begin{array}{l}q e_{(\mathrm{exp})} \\
\left(\mathrm{mg} \mathrm{g}^{-}\right.\end{array}$ & $\begin{array}{c}k l \\
\left(\mathrm{~min}^{-1}\right)\end{array}$ & $\begin{array}{c}q e_{(\mathrm{cal})} \\
\left(\mathrm{mg} \mathrm{g}^{-1}\right)\end{array}$ & $R$ & $S D$ & $\begin{array}{c}k s \\
\left(\mathrm{~g} \mathrm{mg}^{-1} \mathrm{~min}^{-}\right.\end{array}$ & $\begin{array}{c}q e_{(\mathrm{cal})} \\
\left(\mathrm{mg} \mathrm{g}^{-1}\right)\end{array}$ & $R$ & $S D$ \\
& & & & & & & & & \\
& & & & & & & & \\
5.50 & 24.955 & 0.0353 & 2.940 & 0.877 & 0.565 & 0.0218 & 25.335 & 0.995 & 0.389 \\
6.50 & 24.615 & 0.0564 & 4.207 & 0.819 & 1.044 & 0.0254 & 25.259 & 0.996 & 0.374 \\
\hline
\end{tabular}

Besides, the results of intraparticle diffusion (Figure 7) showed that the diffusion of dye molecules into the chitosan powder occurred at both $\mathrm{pH}$ values. We also observed a second linear region, that is possibly related to diffusion occurring at a second layer, also known as macropore layer [24]. The equilibrium is probably achieved in this region, without further penetration of the dye into a third and inner layer. 

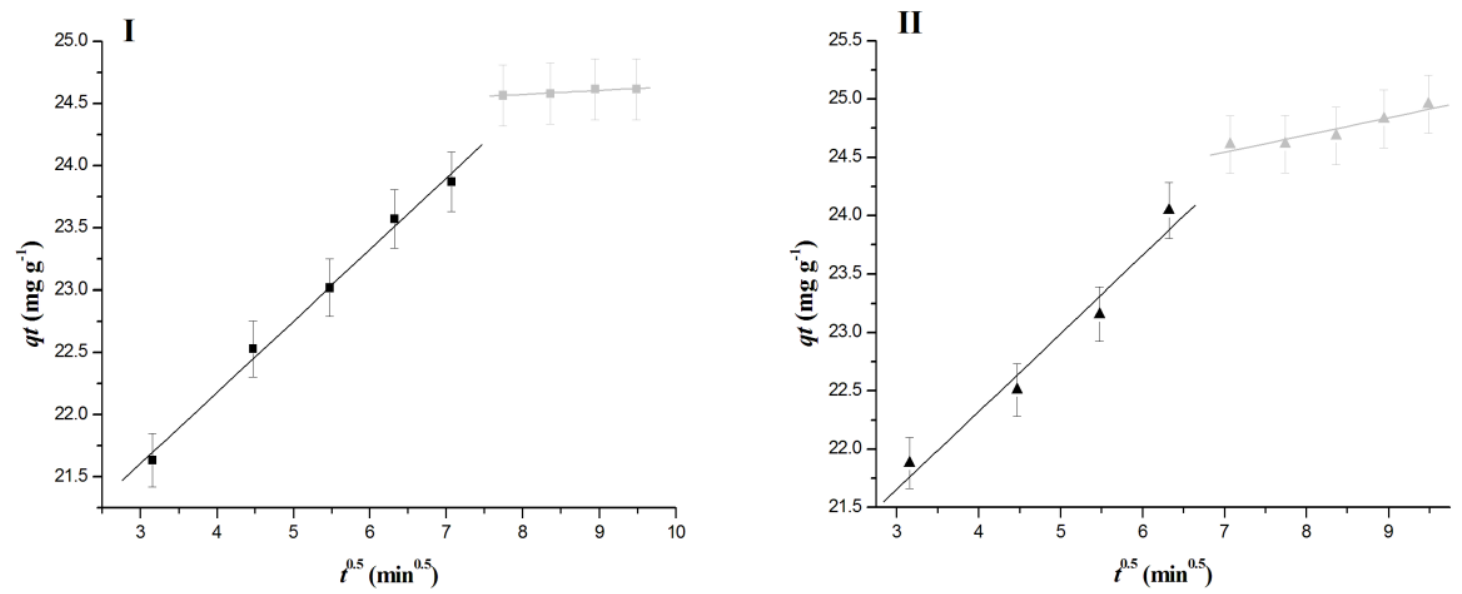

Figure 7: Intraparticle diffusion: I - Dye solution at pH 6.50 ( macropore layer; - mesopore layer) and II - Dye solution at pH 5.50 ( $\Delta$ macropore layer; $\Delta$ mesopore layer).

The intraparticle diffusion constants on Table 3 show that the $K d i$ values of the macropore layer were lower than the first boundary layer. In other words, the diffusion primarily occurred in the second layer (mesopore) by filling all the possible sites in that region before filling the first layer. The constant of diffusion layer thickness was higher in the macropore layer, which indicates its major resistance to dye penetration compared to the first boundary layer. This corroborates our aforementioned results of intraparticle diffusion.

Table 3: Constants values of intraparticle diffusion

\begin{tabular}{ccccccccc}
\hline pH & \multicolumn{7}{c}{ First boundary layer } & Macropore layer \\
\hline & $\begin{array}{c}K d i \\
\left(\mathrm{mg} \mathrm{g}^{-1}\left(\mathrm{~min}^{0.5}\right)^{-1}\right)\end{array}$ & $\begin{array}{c}C \\
\left(\mathrm{mg} \mathrm{g}^{-1}\right)\end{array}$ & $R$ & $S D$ & $\begin{array}{c}K d i \\
\left(\mathrm{mg} \mathrm{g}^{-1}\left(\mathrm{~min}^{0.5}\right)^{-1}\right)\end{array}$ & $\begin{array}{c}C \\
\left(\mathrm{mg} \mathrm{g}^{-1}\right)\end{array}$ & $R$ & $S D$ \\
6.5 & 0.573 & 19.882 & 0.997 & 1.192 & 0.032 & 24.317 & 0.948 & 2.178 \\
5.5 & 0.668 & 19.648 & 0.983 & 0.603 & 0.147 & 23.508 & 0.941 & 0.983 \\
\hline
\end{tabular}

The Boyd plot ( $B t$ vs. $t$ ) further confirmed that diffusion is not controlling the sorption process at both $\mathrm{pH}$ values since the regression function did not pass through the origin of the coordinate plane (Figure 8). We propose that the main sorption site is on the surface, as the actual adsorption controller.
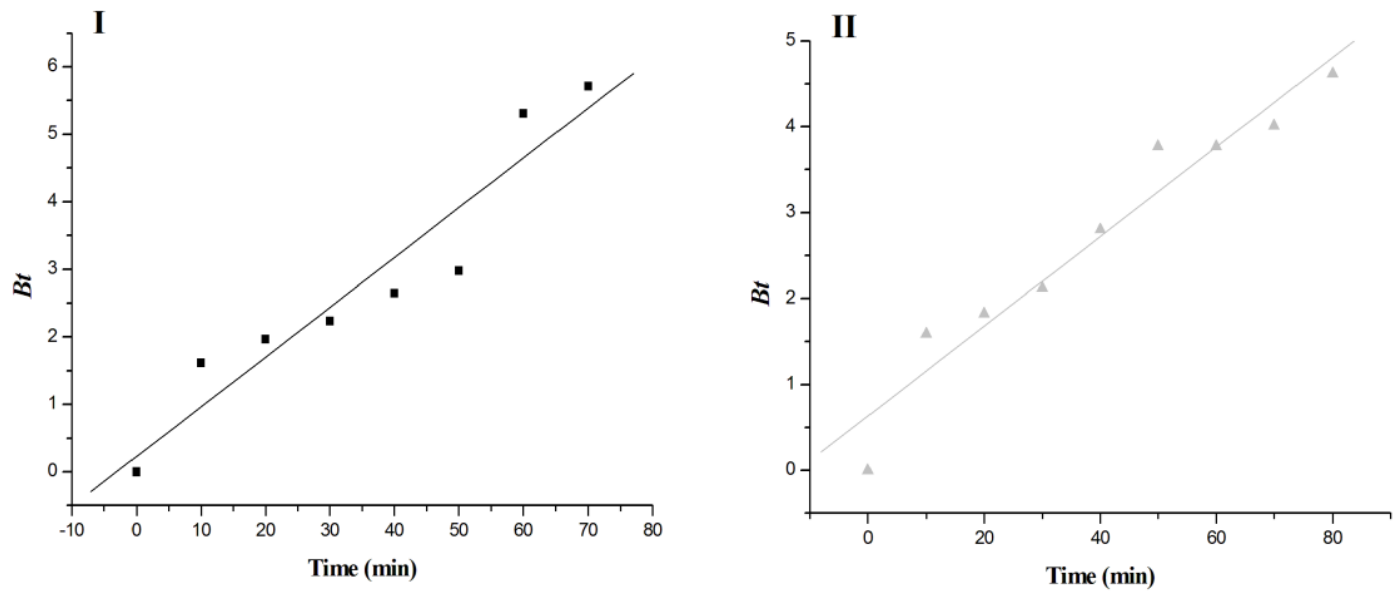

Figure 8: Boyd function: I - Dye solution at pH 6.50 and II - Dye solution at pH 5.50. 
The $B b$ values for $\mathrm{pH} 6.50$ and 5.50 were 0.0737 and 0.0521 respectively, whereby it was possible to determine the $D i$ values for both $\mathrm{pH}$, being $5.851 \times 10^{-7} \mathrm{~cm}^{2} \mathrm{~s}^{-1}$ at $\mathrm{pH} 6.50$, and $4.137 \times 10^{-7} \mathrm{~cm}^{2} \mathrm{~s}^{-1}$ at $\mathrm{pH}$ 5.50. The values of $D i$ on the order of $10^{-7} \mathrm{~cm}^{2} \mathrm{~s}^{-1}$ confirms that the adsorption took place on both the external and internal surfaces, being much more intense on the surface.

Based on the isotherms and kinetics, we observed that a specific sorption site promoted chemical interaction. Therefore, it was necessary to understand the main sites of possible chemisorption to propose a mechanism that could explain the interaction between the dye and the biopolymer. The DO 2GL dye has sulfonic functional groups $\left(\mathrm{SO}_{3}^{-}\right)$and the chitosan amino functional groups $\left(\mathrm{NH}_{2}\right)$, which gives it ionic interactions capabilities. As a result, any $\mathrm{pH}$ changes in the solution is supposed to interfere with the charges and electrostatic interactions between the adsorbate and the adsorbent. The protonated chitosan $\left(\mathrm{NH}_{3}{ }^{+}\right)$allows a more efficient interaction with charged dye molecules (Figure 9), being one of the main reasons for the adsorption to be more efficient in a more acidic $\mathrm{pH}$, as observed in this work.

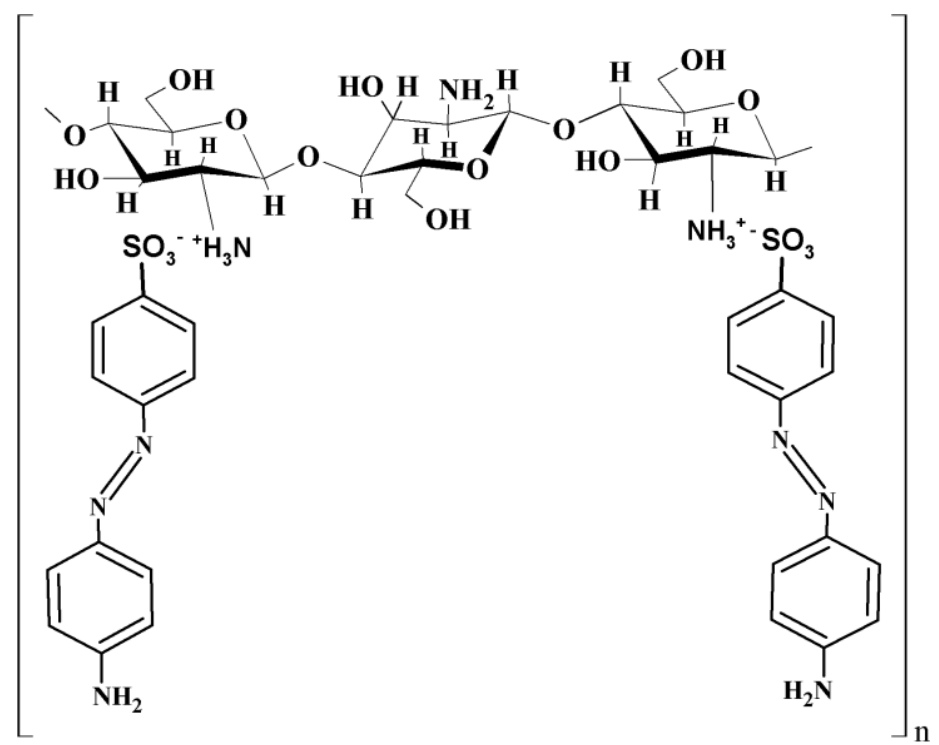

Figure 9: Possible chemical interaction between the chitosan powder and DO 2GL dye.

Thus, a solution set to an acid medium induces the electrostatic interactions that result in the protonation of the amino groups. Therefore, in the presence of acidified aqueous solutions, the functional groups of the chitosan molecule are positively charged and promote strong interactions between the free valences of the amino groups $\left(\mathrm{NH}_{3}{ }^{+}\right)$and the anions of the sulfonic radical groups $\left(\mathrm{SO}_{3}^{-}\right)$belonging to the dye. This type of interaction with chitosan can be extended to other sulfonic dyes.

Based on the maximum effluent disposal regulations in Brazil [17], along with the tolerable spectrophotometric pattern of dye traces in water for disposal in the environment [30], we can stipulate the monthly costs of treating effluents using the chitosan powder as an adsorbent in a treatment system similar to Jar-Test. Not taking into account electricity, maintenance and equipment costs, and assuming that the adsorbent price is from a Brazilian supplier with fixed capital without inflation effects, it would be necessary to spend approximately US $\$ 7,075.27$ per month to treat a $100 \mathrm{~m}^{3}$ effluent with a concentration of $0.05 \mathrm{~g} \mathrm{~L}^{-1}$ of textile dye. A specific amount of adsorbent material may be required to remove the dye according to their respective adsorbate/adsorbent interactions when we consider that the dye to be treated would be DO 2GL. The average price of chitosan powder is US\$10.61 per $\mathrm{kg}$, while the activated carbon quoted in this work has an average cost of US\$ 9.65 per $\mathrm{kg}$, however, due to its high interaction with reactive sulfonic dyes, chitosan becomes more cost-effective. Therefore, chitosan powder can be considered a very feasible adsorbent agent of dyes in industrial scale effluent treatment.

\section{CONCLUSION}

Chitosan powder was a good adsorbent material according to our experimental approach. We propose that it is reasonable replacement for activated carbon, which is currently used in most adsorptive treatments. Besides, chitosan is a low-cost material that is also widely available, at a similar cost range. 
Adsorption is more efficient at acidic $\mathrm{pH}$, due to the interactions of the ionic bonds between the amine groups $\left(\mathrm{NH}_{3}{ }^{+}\right)$of the adsorbent with the sulfonic groups $\left(\mathrm{SO}_{3}{ }^{-}\right)$of the adsorbate. Isotherm analysis confirmed that the adsorption occurs due to chemisorption. The kinetic studies showed that chitosan powder reached sorption equilibrium in 60 minutes, which is an ideal time frame for industrial scale treatment.

More studies with industrial chitosan powder are encouraged to evaluate its adsorption capabilities towards other different types of textile dyes or even in dye mixtures. Nevertheless, the use of chitosan powder as adsorbent is recommended for a large-scale treatment of effluents textiles.

\section{ACKNOWLEDGEMENTS}

Support from the Brazilian fostering agencie: Coordenação de Aperfeiçoamento de Pessoal Nível Superior (CAPES) Brazil.

\section{BIBLIOGRAPHY}

[1] GONG, R., ZHANG, X., LIU, H., et al. "Uptake of cationic dyes from aqueous solution by biosorption onto granular kohlrabi peel”. Bioresource Technology, v. 98, pp. 1319-1323, 2007.

[2] GHAZI MOKRI, H.S., MODIRSHAHLA, N., BEHNAJADY, M.A., et al. "Adsorption of C.I. Acid Red 97 dye from aqueous solution onto walnut shell: kinetics, thermodynamics parameters, isotherms". International Journal of Environmental Science and Technology, v. 12, pp. 1401-1408, 2015.

[3] RAVAL, N.P., SHAH P.U., SHAH, N.K. "Adsorptive amputation of hazardous azo dye Congo red from wastewater: a critical review”. Environmental Science and Pollution Research, v. 23, pp. 14810-14853, 2016.

[4] TOOR, A.P., VERMA, A., JOTSHI, C.K., et al. "Photocatalytic degradation of Direct Yellow 12 dye using UV/TiO, in a shallow pond slurry reactor”. Dyes and Pigments, v. 68, pp. 53-67, 2006.

[5] THINAKARAN, N., PANNEERSELVAM, P., BASKARALINGAM, et al., "Equilibrium and kinetic studies on the removal of acid red 114 from aqueous solutions using activated carbons prepared from seed shells". Journal of Hazardous Materials, v. 158, pp. 142-150, 2009.

[6] CONTRERAS, L., SEPULVEDA, L., PALMA, C. "Valorization of Agro-industrial Wastes as Biosorbent for the Removal of Textile Dyes from Aqueous Solutions". International Journal of Chemical Engineering, v. 2012, pp. 9-23, 2012.

[7] GALINDO, C., KALT, A. "UV/ $\mathrm{H}_{2} \mathrm{O}_{2}$ oxidation of azodyes in aqueous media: evidence of a structure degradability relationship", Dyes and Pigments, v. 42, pp. 199-207, 1999.

[8] SANTOS, P.K., FERNANDES, K.C., FARIA, L.A., et al. "Discoloration and degradation of the RED GRLX-220 azo-dye by ozonation”, Química Nova, v. 34, pp. 1315-1322, 2011.

[9] BRUNELLI, T.F.T., GUARALDO, T.T., PASCHOAL, F.M.M., et al. "Photoeletrochemical degradation of disperse dyes in textile effluent on photoanodes of Ti/TiO 2 ", Química Nova, v. 32, pp. 67-71, 2009.

[10] HOSSEINI, S.D., ASGHARI, F.S., YOSHIDA, H. "Decomposition and discoloration of synthetic dyes using hot/liquid (subcritical) water”. Water Research, v. 44, pp.1900-1908, 2010.

[11] PARMAR, N.D., SHUKLA, S.R. "Biodegradative decolorization of Reactive Red 195-A by an isolated bacteria Staphylococcus sp: studies on metabolites and toxicity", Desalination and Water Treatment, v. 63, pp. 241-253, 2017.

[12] CHOY, K.K.H.; PORTER, J.F.; MCKAY, G. "Langmuir, isotherms models applied to the multicomponent sorption of acid dyes from effluent onto activated carbon", Journal of Chemical \& Engineering, v. 45, pp. 575-584, 2000.

[13] SHARMA, P.; KAUR, H.; SHARMA, M.; et al. "A review on applicability of naturally available adsorbents for the removal of hazardous dyes from aqueous waste", Environmental Monitoring and Assessment, v. 183, pp. 151-195, 2011.

[14] KNORR, D. "Recovery and utilization of chitin and chitosan in food processing waste management", Food Technology, v. 45, pp. 114-122, 1991.

[15] NGAH, W.S.W., ARIFF, N.F.M., HANAFIAH, M.A.K.M. Preparation, characterization, and environmental application of crosslinked chitosan-coated bentonite for tartrazine adsorption from aqueous solutions. Water, Air \& Soil Pollution, v. 38, pp. 394-411, 2010.

[16] KRISTBERGSON, K.; EINARSSON, J.M.; HAUKSSON, S.P.; et al.. "Recent Developments in desacetylation of chitin, and possible applications in food formulations", New York: Print Current Journal, 2003. 
[17] BRASIL. Ministério do Meio Ambiente, Conselho Nacional de Meio Ambiente, CONAMA. Resolução CONAMA n430/2011, de 13 de Maio de 2011- In: Resoluções, 2011. Disponível em:

$<$ http://www.mma.gov.br> Acesso em: 22/05/2019

[18] LANGMUIR, I. "The adsorption of gases on plane surface of glass, mica and platinum". Journal of the American Chemical Society, v. 40, pp. 1361-1368, 1918.

[19] FREUNDLICH, H. “Adsorption in solution”, Journal of Physical Chemistry, v. 40, pp. 1361-1368, 1906.

[20] PODKOSCIELNY, P.; NIESZPOREK, K. "Adsorption of phenols from aqueous solutions: equilibrium, calorimetry and kinetics of adsorption", Journal of Colloid and Interface Science, v. 354, pp. 282-291, 2011.

[21] MCKAY, G.; BLAIR, H.S.; GARDNER, J.R. "Adsorption of dyes on chitin: equilibrium studies", Journal of Applied Polymer Science, v. 27, pp. 30-43, 1982.

[22] SABER-SAMANDARI, S.; HEYDARIPOUR, J. "Onion membrane: an efficient adsorbent for decoloring of wastewater", Journal of Environmental Health Science \& Engineering, v. 13, p.16- 33, 2015.

[23] LAGERGREN, S. Z. "The theory of adsorption of substances", Handlingar, v. 24, pp.1-39, 1898.

[24] HO, Y.S., MCKAY, G. "Sorption of dye from aqueous solution by peat", Chemical Engineering Journal, v. 70, pp. 115-124, 1998.

[25] WEBER, W.J., MORRIS, J.C. "Kinetics of adsorption on carbon from solution", Journal of the Sanitary Engineering Division, v. 89, pp. 31-60, 1963.

[26] BOYD, G.E., ADAMSON, A.W., MYERS, L.S. "The exchange adsorption of ions from aqueous solution by organic zeolites, II, Kinetics". Journal of the American Chemical Society, v. 69, pp. 2836-2848, 1947.

[27] ARAVINDHAN, R., RAO, J.R., NAIR, B.U. "Removal of basic yellow dye from aqueous solution by sorption on green algae Caulerpa scalpelliformis". Journal of Hazardous Materials, v. 142, pp. 68-76, 2007. [28] SAFA, Y., BHATTI, H. N. "Biosorption of Direct Red-31 and Direct Orange-26 dyes by rice husk: Application of factorial design analysis". Chemical Engineering Research and Design, 566-2574, 2011.

[29] NANDI, B.K., GOSWAMI, A., PURKAIT, M.K. "Adsorption characteristics of brilliant green dye on kaolin”. Journal of Hazardous Materials, v.161, pp.387-395, 2009.

[30] COOPER, P. "Removing colour from dye house waste waters - a critical review of technology available", Journal of the Society of Dyes and Colourists Coloration Technology, v. 109, pp. 97-100, 1993.

\section{ORCID}

Carolina Rosai Mendes $\quad$ http://orcid.org/0000-0003-0008-7372

Guilherme Dilarri http://orcid.org/0000-0003-2625-7392

Ederio Dino Bidoia $\quad$ http://orcid.org/0000-0001-7040-1983

Renato Nallin Montagnolli http://orcid.org/0000-0003-3801-9631 